\title{
Efek Ekstrak Angkak dalam Menghambat Proliferasi Sel Kanker Prostat dan Payudara
}

\author{
Tiana Milanda, Anisa Aprilia, Zakiatun A. Amani, Yuni E. Hadisaputri, Vesara A. Gatera
} Departemen Biologi Farmasi, Fakultas Farmasi, Universitas Padjadjaran, Sumedang, Indonesia

\begin{abstract}
Abstrak
Kanker payudara dan prostat masih menjadi kasus prevalensi tertinggi hingga saat ini, untuk itu diperlukan beberapa alternatif terapi yang berasal dari bahan alam dengan efek samping yang relatif rendah. Salah satu bahan alam yang memiliki aktivitas sitotoksisitas adalah angkak yang merupakan hasil fermentasi dari jamur Monascus pada medium beras, namun potensinya belum optimal diteliti terutama pada kanker payudara dan prostat. Penelitian ini bertujuan untuk menguji sitotoksisitas ekstrak etanol, etil asetat, dan $n$-heksan dari angkak terhadap lini sel kanker prostat DU145, lini sel kanker payudara MDA-MB-231 dan menentukan golongan senyawa yang diduga memiliki aktivitas sitotoksik. Penelitian ini menggunakan metode 3-4,5-di-methylthiazol-2-yl-5-(3-carboxymethoxyphenyl)-2(sulfophenyl)-2H-tetrazolium (MTS). Berdasarkan hasil penelitian, diketahui bahwa ekstrak $n$-heksan memiliki sitotoksisitas terbaik dengan nilai IC $_{50} 138,900 \mu \mathrm{g} / \mathrm{mL}$ pada lini sel DU145 dan 192,623 $\mu \mathrm{g} / \mathrm{mL}$ pada lini sel MDA-MB-231, sedangkan pada ekstrak etanol dan etil asetat memiliki tingkat sitotoksik yang rendah dengan masing-masing nilai $\mathrm{IC}_{50}$ yaitu $649,426 \mu \mathrm{g} / \mathrm{mL}$ pada lini sel DU145, di luar rentang konsentrasi uji pada sel lini MDA-MB-231 dan 207,916 $\mu \mathrm{g} / \mathrm{mL}$ pada lini sel DU145 dan 259,408 $\mu \mathrm{g} /$ $\mathrm{mL}$ pada lini sel MDA-MB-231. Disimpulkan bahwa ekstrak n-heksan angkak memiliki aktivitas sitotoksisitas terbaik, kemampuan tersebut diduga berasal dari senyawa flavonoid dan kuinon.
\end{abstract}

Kata kunci: Angkak, kanker prostat, Monascus, sitotoksisitas

\section{The Effect of Angkak Extract in Inhibiting Cell Proliferation of Prostate and Breast Cancer}

\begin{abstract}
Prostate cancer attacks the prostate gland in the male reproductive system. However, angkak, a product of fermentation from Monascus mushrooms on rice medium, exhibits potent anticancer activity. This study, therefore, aims to examine the cytotoxicity of ethanol, ethyl, and n-hexane extracts from angkak against DU145 prostate, as well as MDA-MB-231 breast cancer cells line, and determine the class of compounds with cytotoxic activity. The cytotoxic assay was performed using the 3-4,5-di-methylthiazol2-y1)-5-(3-carboxymethoxyphenyl)-2-(4-sulfophenyl)-2H-tetrazolium (MTS) method. According to the results, the n-hexane extract of angkak exhibited the most impressive cytotoxicity at $\mathrm{IC}_{50} 138,900 \mu \mathrm{g} / \mathrm{mL}$ in DU145 cell, and 192,623 $\mu \mathrm{g} / \mathrm{mL}$, in MDA-MB-231 cell line. Meanwhile, the ethanol and ethyl acetate extracts exhibited low cytotoxic levels with $\mathrm{IC}_{50} 649,426 \mu \mathrm{g} / \mathrm{mL}$ and $207,916 \mu \mathrm{g} / \mathrm{mL}$, respectively, in DU145 cell line, as well as unidentified results and 259,408 $\mu \mathrm{g} / \mathrm{mL}$, respectively, in MDA-MB-231 cell line. Therefore, angkak n-hexane extract was concluded to exhibit the best cytotoxicity activity, with the potential compounds having this activity derived from flavonoid and quinone compounds.
\end{abstract}

Keywords: Angkak, prostate cancer, Monascus, cytotoxicity

\footnotetext{
Korespondensi: Dr. apt. Tiana Milanda, M.Si., Departemen Biologi Farmasi, Fakultas Farmasi, Universitas Padjadjaran, Sumedang, Jawa Barat 45363, Indonesia, email: tiana.milanda@unpad.ac.id

Naskah diterima: 11 Maret 2021, Diterima untuk diterbitkan: 20 Juni 2021, Diterbitkan: 30 Juni 2021
} 


\section{Pendahuluan}

Menurut American Cancer Society (2018) dan hasil penelitian yang dilakukan Mistry et al. (2011), kanker masih menjadi problematika di seluruh dunia dengan angka prevalensi yang relatif meningkat terutama kanker prostat dan payudara. ${ }^{1,2}$ Indonesia menempati peringkat kedelapan di Asia Tenggara untuk angka prevalensi kanker (136,2/100.000 penduduk). Data riset kesehatan dasar (Riskesdas) juga melaporkan bahwa prevalensi kanker meningkat tiap tahunnya dari 1,4 per 1.000 penduduk pada tahun 2013 menjadi 1,79 per 1.000 penduduk pada tahun $2018 .^{3,4}$

Pada tahun 2010 , sekitar $26 \%$ pria yang menderita kanker di United Kingdom (UK) dan Wales menderita kanker prostat. ${ }^{2}$ Pada tahun 2012, sebanyak 1.112 kasus kanker prostat terjadi di seluruh dunia dengan 307 di antaranya meninggal dunia. Risiko yang relatif sama terjadi pada kanker payudara. Jumlah kasus kanker payudara pada tahun 2012 menduduki peringkat kedua di dunia, yaitu sebanyak 1.670.000 dan mengakibatkan 522.000 kasus kematian. ${ }^{5}$ Berdasarkan Pusat Data dan Informasi Kementerian Kesehatan Republik Indonesia (2015), pada tahun 2013 prevalensi kanker prostat di Indonesia sebesar $0,2 \%$ atau diperkirakan sebanyak 25.012 penderita, dan kanker payudara merupakan prevalensi kedua tertinggi sebesar 61.682. ${ }^{6}$

Upaya untuk mengendalikan kasus kanker relatif berkembang, namun pengobatannya juga tergantung pada status dan tingkatan penyakit, dan usia penderita. Pengobatan yang dilakukan bervariasi, mulai dari prostatektomi radikal, radioterapi, terapi hormonal, dan kemoterapi. Pengobatan kanker yang sifatnya toksik pada sel normal dapat menimbulkan efek samping lain dengan gejala seperti mual, muntah, anoreksia, diare, dan mukositis pada mulut. Efek samping ini dapat menurunkan kualitas hidup pasien, sehingga pasien sulit untuk melanjutkan terapi tersebut. ${ }^{7}$
Salah satu bahan alam yang memiliki potensi terhadap kanker adalah angkak yang merupakan hasil fermentasi Monascus sp. di beras dan sejak lama dikenal dan digunakan pada pengobatan tradisional Cina. ${ }^{8}$ Berdasarkan penelitian yang telah dilakukan, dilaporkan bahwa angkak memiliki aktivitas sitotoksik terhadap lini sel kanker payudara MCF7 dan lini sel kanker hati HepG2.9,10 Pada penelitian lain oleh Shang et al. (2011), telah dilakukan penelitian mengenai pengujian sitotoksisitas pada angkak terhadap lini sel kanker paru A549 dan lini sel kanker ovarium A2780. ${ }^{11}$

Pada penelitian ini, dilakukan pengujian sitotoksisitas dari ekstrak angkak terhadap lini sel kanker prostat DU145 dan lini sel kanker payudara MDA-MB-231 sebagai kandidat terapi kanker. Pengujian ini menggunakan metode MTS Assay dengan variasi konsentrasi bahan uji yang digunakan.

\section{Metode}

Identifikasi ekstraksi dan penapisan fitokimia angkak

Bahan yang digunakan dalam penelitian ini adalah angkak yang diperoleh dari PT. Global Buana Mandiri, Jakarta, Indonesia. Identifikasi kapang pada angkak dilakukan dengan cara membandingkan karakteristik mikroskopis dan makroskopis antara kapang pada angkak dengan kapang Monascus purpureus ITBCCL61. Identifikasi secara makroskopis dilakukan dengan menghaluskan 10 butir angkak dengan penambahan aquades steril, ${ }^{12}$ dan diinokulasi ke media saburoud dalam cawan petri. Selanjutnya cawan petri diinkubasi pada suhu kamar selama 7 hari lalu diamati karakteristik makroskopisnya. Untuk pengamatan mikroskopis, setelah diinkubasi, kultur kapang diamati secara langsung di bawah mikroskop. ${ }^{13}$ Untuk proses ekstraksi, sebanyak $2 \mathrm{~kg}$ angkak ditimbang lalu dimaserasi menggunakan $n$-heksan. Setelah diperoleh filtrat bening, angkak dikeringkan 
menggunakan oven pada suhu $50^{\circ} \mathrm{C}$. Setelah kering, angkak dimaserasi kembali dengan pelarut etanol $96 \%$ sama seperti perlakuan sebelumnya. Selanjutnya dilakukan penapisan fitokimia angkak untuk mengetahui golongan senyawa flavonoid, alkaloid, steroid dan triterpenoid, tannin dan polifenol, saponin, serta kuinon yang terkandung di dalam ekstrak angkak.

\section{Preparasi ekstrak}

Masing-masing ekstrak dilarutkan dengan DMSO dan aqua bidestillata sehingga didapat larutan stok ekstrak masing-masing dengan konsentrasi $4000 \mu \mathrm{g} / \mathrm{mL}$. Konsentrasi larutan uji yang digunakan adalah 7,81 $\mu \mathrm{g} / \mathrm{mL}, 15,63$ $\mu \mathrm{g} / \mathrm{mL}, 31,25 \mu \mathrm{g} / \mathrm{mL}, 62,50 \mu \mathrm{g} / \mathrm{mL}, 125 \mu \mathrm{g} /$ $\mathrm{mL}, 250 \mu \mathrm{g} / \mathrm{mL}, 500 \mu \mathrm{g} / \mathrm{mL}$, dan $1000 \mu \mathrm{g} / \mathrm{mL}$.

Kultur lini sel DU145 dan MDA-MB-231

Lini sel yang digunakan pada penelitian ini merupakan koleksi Laboratorium Biokimia Klinis Fakultas Farmasi Universitas Padjadjaran. Lini sel kanker prostat DU145 dikultur dengan menggunakan medium RPMI-1640 dan lini sel kanker payudara MDA-MB-231 dikultur menggunakan medium DMEM yang masing-masing mengandung 10\% fetal bovine serum dan $1 \%$ penisilin-streptomisin. Kultur dilakukan dengan kondisi oksigen 5\% dan suhu $37^{\circ} \mathrm{C}$. Setelah sel mencapai konfluensi yang diinginkan, sel dipanen dengan menggunakan TrypLE dan sel dihitung dengan mennggunakan haemocytometer.

Uji sitotoksisitas dengan MTS Assay

Sebanyak $50 \mu \mathrm{L}$ suspensi yang berisi $5 \times 10^{3} \mathrm{sel} /$ $\mathrm{mL}$ lini sel kanker prostat DU145 dan lini sel kanker payudara MDA-MB-231 dimasukkan dengan pipet mikro ke dalam 96 sumuran microplate, selanjutnya diinkubasi selama 24 jam di inkubator $37^{\circ} \mathrm{C}, 5 \% \mathrm{CO}_{2}$. Kemudian medium kultur ditambahkan dengan ekstrak etanol, etil asetat, dan $n$-heksan angkak dengan variasi konsentrasi 7,81 $\mu \mathrm{g} / \mathrm{mL}, 15,63$ $\mu \mathrm{g} / \mathrm{mL}, 31,25 \mu \mathrm{g} / \mathrm{mL}, 62,50 \mu \mathrm{g} / \mathrm{mL}, 125 \mu \mathrm{g} /$ $\mathrm{mL}, 250 \mu \mathrm{g} / \mathrm{mL}, 500 \mu \mathrm{g} / \mathrm{mL}, 1.000 \mu \mathrm{g} / \mathrm{mL}$ dan diinkubasi selama 24 jam di inkubator $37^{\circ} \mathrm{C}, 5 \% \mathrm{CO}_{2}$. Selanjutnya ke dalam tiap well plate ditambahkan $10 \mu \mathrm{L}$ reagen Cell Counting Kit-8 pada masing-masing well. Kemudian diinkubasi selama 4 jam pada suhu $37^{\circ} \mathrm{C}$. Setelah 4 jam, reaksi pada larutan dihentikan dengan menambahkan $100 \mu \mathrm{L}$ $\mathrm{HCl} 0,1 \mathrm{~N}$ pada tiap well. Selanjutnya diukur absorbansinya pada panjang gelombang 500-600 nm menggunakan spektrofotometer microtiter plate reader.

Analisis data

Analisis data dari pengujian sitotoksisitas dilakukan dengan persentase inhibisi pertumbuhan sel dan nilai $\mathrm{IC}_{50}$ berikut: ${ }^{14}$

$\%$ inhibisi $=\left(1-\frac{(\mathrm{AP}-\mathrm{AM})}{(\mathrm{ASK}-\mathrm{AM})}\right) \times 100 \%$

dengan $\mathrm{AP}=$ absorbansi perlakuan; $\mathrm{AM}=$ absorbansi media; dan $\mathrm{ASK}=$ absorbansi sel kontrol.

$\mathrm{IC}_{50}$ ekstrak angkak dianalisis menggunakan persamaan regresi linear $(y=b x+a)$ antara logaritma konsentrasi ekstrak angkak dengan persentase proliferasi sel.

\section{Hasil}

Hasil identifikasi jamur pada angkak dan pembandingnya menunjukkan adanya koloni jamur yang menyebar dan hifa muda berwarna putih yang lama-lama berubah menjadi kemerahan, dan medium pertumbuhan yang menjadi merah. Warna merah ini menunjukkan hasil dari metabolism jamur Monascus purpureus yang akan menghasilkan pigmen warna merah selama proses metabolisme (Gambar 1). ${ }^{15}$

Dari hasil identifikasi secara mikroskopik, didapatkan bahwa pada angkak dan pada biakkan jamur Monascus terdapat karakter yang terdapat pada jamur Monascus purpureus (Gambar 2). Keduanya memiliki hifa somatik, 
konidia yang bertumpuk dan askomata. Hal ini menunjukkan bahwa angkak yang diperoleh adalah hasil fermentasi dari jamur Monascus purpureus.

Hasil ekstraksi dan penapisan fitokimia angkak Berdasarkan hasil perhitungan rendemen, perbedaan pelarut memengaruhi jumlah ekstrak yang akan didapatkan. Pelarut etanol memiliki persentase rendemen paling tinggi $(9,60 \%)$, diikuti oleh etil asetat $(4,21 \%)$ dan $n$-heksan (2,67\%). Pelarut etanol lebih dapat menarik senyawa-senyawa yang bersifat polar dan semi polar sehingga didapatkan jumlah rendemen yang lebih banyak. Berdasarkan hasil penelitian, ekstrak etanol mengandung senyawa golongan flavonoid, polifenol, kuinon, tanin, dan saponin. Pada ekstrak etil asetat mengandung senyawa alkaloid, flavonoid, polifenol, kuinon, tanin, dan saponin. Ekstrak $n$-heksan mengandung senyawa kuinon dan flavonoid.

Pengujian sitotoksisitas ekstrak angkak pada lini sel kanker prostat DU-145 dan lini sel kanker payudara MDA-MB-231

Uji sitotoksisitas ekstrak angkak diawali dengan perhitungan persentase (\%) inhibisi sel masing-masing ekstrak angkak (Gambar 3 dan 4). Dalam penelitian ini, potensi nilai
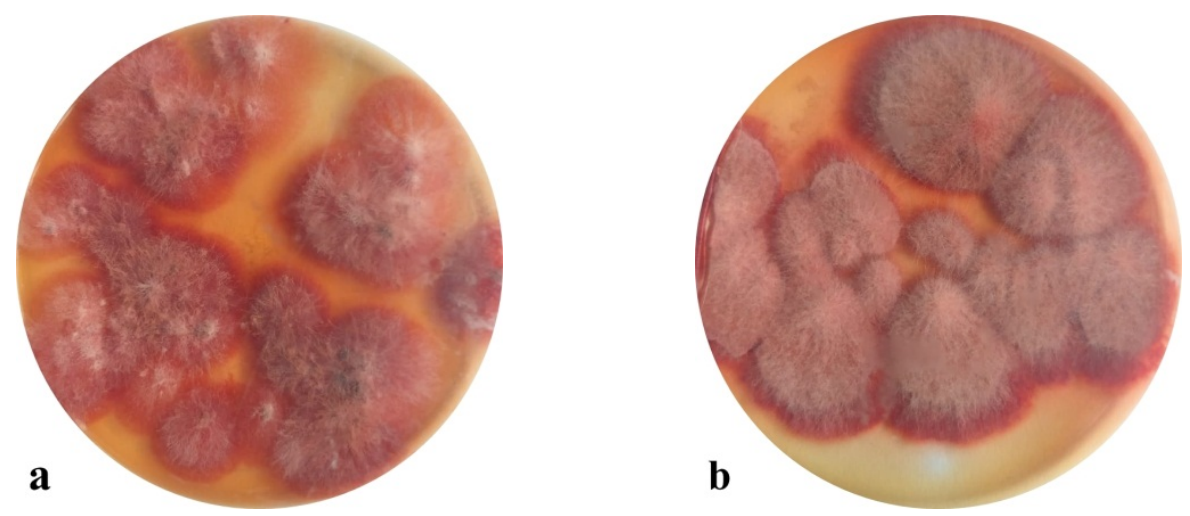

Gambar 1 Hasil Identifikasi secara Makroskopik (a) Jamur dari Angkak dan (b) Monascus purpureus
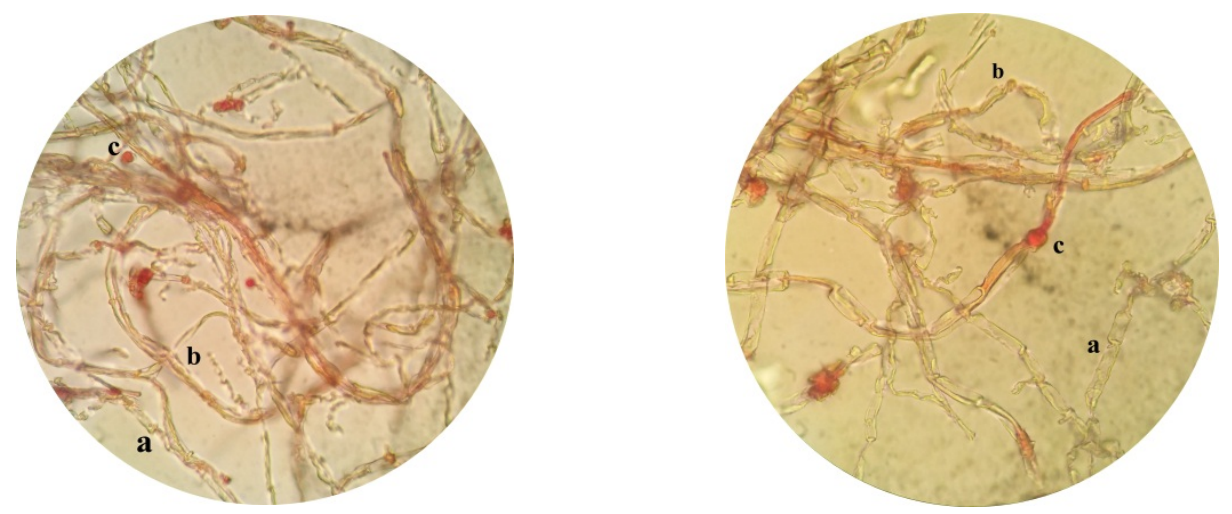

Gambar 2 Hasil Identifikasi Mikroskopik Jamur dari Angkak (Kanan) dan Monascus purpureus (Kiri) Keterangan: a. hifa somatik, b. konid, c. askospora 


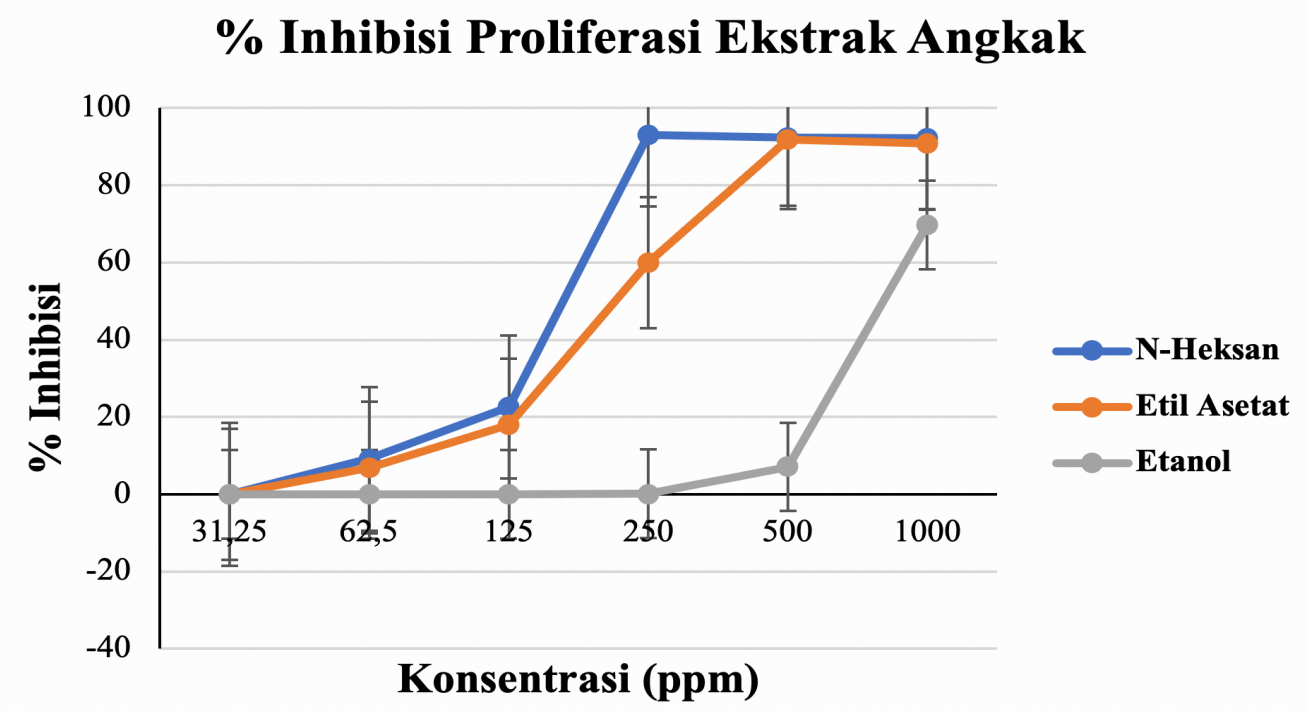

Gambar 3 Perbandingan Persentase Inhibisi Proliferasi Sel dari Ekstrak $n$-Heksan, Ekstrak Etil Asetat, dan Ekstrak Etanol Angkak terhadap Lini Sel Kanker Prostat DU145

$\mathrm{IC}_{50}$ pada lini sel kanker prostat DU-145 dan lini sel kanker payudara MDA-MB-231 pada ekstrak angkak dapat dilihat pada Tabel 1 dan 2.

\section{Pembahasan}

Penelitian ini dilakukan untuk menguji potensi sitotoksisitas dari ekstrak angkak terhadap lini sel kanker prostat DU145 dan lini sel kanker payudara MDA-MB-231 sebagai kandidat terapi kanker. Pengujian ini menggunakan metode MTS Assay dengan variasi konsentrasi bahan uji yang digunakan.

Terdapat beberapa ciri yang digunakan untuk diidentifikasi Monascus purpureus yaitu hifa yang bersekat, konidia yang bertumpuk,

\section{\% Inhibisi Proliferasi Ekstrak Angkak}

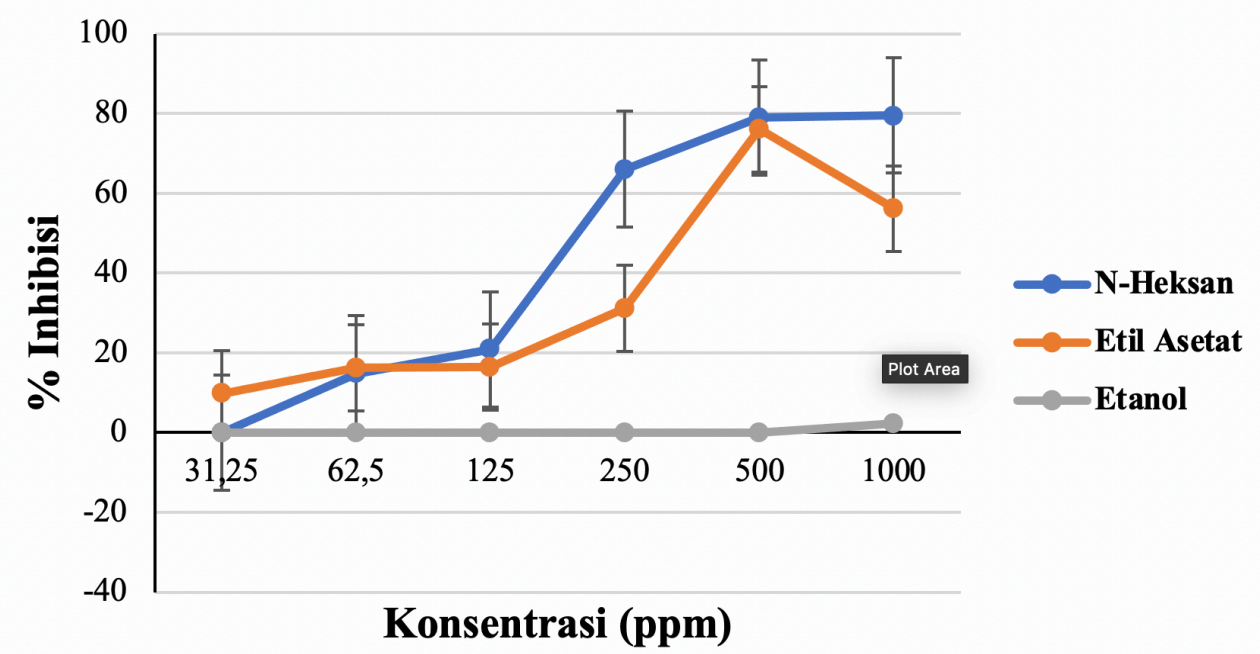

Gambar 4 Perbandingan Persentase Inhibisi Proliferasi Sel dari Ekstrak n-Heksan, Ekstrak Etil Asetat, dan Ekstrak Etanol Angkak terhadap Lini Sel Kanker Payudara MDA-MB-231 
Tabel 1 Nilai Rata-Rata IC $_{50}$ Ekstrak $n$-Heksan, Ekstrak Etil Asetat, dan Ekstrak Etanol Angkak terhadap Lini Sel Kanker Prostat DU145

\begin{tabular}{lcc}
\hline \multicolumn{1}{c}{ Sampel } & ${\text { Nilai } \mathbf{I C}_{\mathbf{5 0}}(\boldsymbol{\mu g} \mathbf{g} \mathbf{m L})}$ & Standar Deviasi \\
\hline Ekstrak $n$-heksan & 138,9 & 45,46 \\
Ekstrak etil asetat & 207,916 & 41,75 \\
Ekstrak etanol & 649,426 & 28,05 \\
\hline
\end{tabular}

Tabel 2 Nilai Rata-Rata IC $_{50}$ Ekstrak $n$-Heksan, Ekstrak Etil Asetat, dan Ekstrak Etanol Angkak terhadap Lini Sel Kanker Payudara MDA-MB-231

\begin{tabular}{lcc}
\hline \multicolumn{1}{c}{ Sampel } & ${\text { Nilai } \mathbf{I C}_{\mathbf{5 0}}(\boldsymbol{\mu \mathbf { g }} / \mathbf{m L})}^{\text {Standar Deviasi }}$ \\
\hline Ekstrak $n$-heksan & 192,623 & 35,46 \\
Ekstrak etil asetat & 259,408 & 26,36 \\
Ekstrak etanol & $>1000$ & 0,90 \\
\hline
\end{tabular}

dan adanya ascomata. ${ }^{16}$ Pada identifikasi ini digunakan pembanding yaitu biakan jamur Monascus purpureus. Hasil identifikasi secara makroskopik dapat dilihat pada Gambar 1 dan hasil identifikasi secara mikroskopik dapat dilihat pada Gambar 2.

Penapisan fitokimia dilakukan dengan tujuan untuk mengetahui golongan senyawa yang terkandung dalam ekstrak $n$-heksan, etil asetat, dan etanol dari angkak. Penapisan fitokimia dilakukan terhadap golongan metabolit sekunder seperti alkaloid, flavonoid, polifenol, tanin, monoterpen, sesquiterpen, steroid, triterpen, kuinon, dan saponin. Hasil penelitian ini relatif sama dengan penelitian Ismail et al. (2016) menyatakan bahwa ekstrak angkak mengandung flavonoid dan saponin, ${ }^{17}$ sedangkan Cheng et al. (2010) melaporkan bahwa ekstrak angkak memiliki kandungan kuinon. ${ }^{18}$ Masing-masing ekstrak memiliki metabolit yang berbeda, hal ini dikarenakan sifat kepolaran yang berbeda dari masingmasing pelarut. Senyawa seperti flavonoid, saponin, polifenol, tanin umumnya bersifat polar hingga semi polar sehingga dapat tertarik pada pelarut semi polar hingga polar. Senyawa steroid dan terpenoid merupakan senyawa non-polar yang dapat tertarik oleh pelarut n-heksan atau kloroform.
Aktivitas sitotoksitas digambarkan melalui hasil perhitungan nilai $\mathrm{IC}_{50}$, nilai ini menunjukkan potensi ekstrak angkak sebagai senyawa sitotoksik. Menurut Subarnas et al. (2012), tingkat sitotoksisitas dari ekstrak dapat dibagi menjadi kuat $(<100 \mu \mathrm{g} / \mathrm{mL})$, sedang (101-200 $\mu \mathrm{g} / \mathrm{mL})$, dan lemah $(>200 \mu \mathrm{g} /$ $\mathrm{mL}$ ). Semakin besar nilai $\mathrm{IC}_{50}$, maka senyawa tersebut semakin tidak toksik dan sebaliknya, semakin kecil nilai $\mathrm{IC}_{50}$ maka semakin tinggi sifat sitotoksisitas. ${ }^{19}$

Berdasarkan hasil penelitian ini, ekstrak $n$-heksan memiliki aktivitas yang paling baik dibandingkan dengan dua ekstrak lainnya. Ekstrak $n$-heksan termasuk ke dalam tingkat sitotoksik sedang dengan nilai $\mathrm{IC}_{50}$ sebesar $138,900 \mu \mathrm{g} / \mathrm{mL}$ pada lini sel kanker prostat DU145; 192,623 $\mu \mathrm{g} / \mathrm{mL}$ pada lini sel kanker payudara MD-MB-231, diikuti dengan ekstrak etil asetat yang memiliki aktivitas sitotoksik lemah dengan nilai $\mathrm{IC}_{50}$ sebesar $207,916 \mu \mathrm{g} / \mathrm{mL}$ pada lini sel kanker prostat DU145; 259,408 $\mu \mathrm{g} / \mathrm{mL}$ pada lini sel kanker payudara MD-MB-231, sedangkan ekstrak etanol angkak tidak terlihat adanya aktivitas sitotoksik dengan nilai IC50 sebesar 649,426 $\mu \mathrm{g} / \mathrm{mL}$ pada lini sel kanker prostat DU145 dan tidak terdefinisi pada lini sel kanker payudara MD-MB-231. Rendahnya aktivitas 
sitotoksik pada ekstrak etil asetat dan etanol dapat disebabkan metabolit sekunder yang berperan sebagai senyawa sitotoksik kurang tertarik oleh pelarut etil astetat dan etanol. Senyawa yang diduga memiliki aktivitas sitotoksik pada angkak adalah senyawa golongan flavonoid dan kuinon.

Pada penelitian yang dilakukan oleh Lee et al. (2013), dilaporkan bahwa ekstrak etanol dan ekstrak etil asetat angkak memiliki aktivitas sitotoksik selektif terhadap lini sel kanker payudara MCF-7. Ekstrak angkak dilaporkan menginduksi apoptosis melalui aktivasi caspase-9 dan caspase-3. Selain itu, ekstrak angkak meningkatkan ekspresi protein BAX dan menurunkan ekpresi BCL-2 protein yang berkontribusi terhadap aktivitas apoptosis. Lee et al. (2013) lebih lanjut menjelaskan bahwa ekstrak angkak menginduksi populasi sel pada fase G2/M. ${ }^{9}$

Salah satu pigmen jingga dari angkak yaitu rubropunctatin telah diteliti aktivitas sitotoksisitasnya. Xu et al. (2017) melaporkan bahwa rubropunctatin memiliki kemampuan sebagai inhibitor telomerase yang dapat mengakibatkan kematian sel. Mekanisme rubropuncatin yaitu dengan melakukan supresi ekspresi gen human telomeraserelated protein (hTERT). ${ }^{20}$

Kandungan flavonoid dan kuinon yang terdapat pada ekstrak angkak juga berkontribusi sebagai induksi apoptosis dan pencegah perkembangan kanker. Batra et al. (2013) menjelaskan bahwa flavonoid dapat menekan activator protein-1 (AP-1). Regulasi gen AP-1 merupakan modulator penting untuk invasi dan metastasis, angiogenesis, proliferasi, dan diferensiasi. ${ }^{21}$

\section{Simpulan}

Ekstrak $n$-heksan angkak memiliki tingkat sitotoksisitas paling tinggi dibandingkan dengan ekstrak etil asetat dan ekstrak etanol angkak. Senyawa yang diduga memiliki aktivitas sitotoksisitas untuk ekstrak $n$-heksan angkak adalah flavonoid dan kuinon.

\section{Pendanaan}

Penelitian ini tidak didanai oleh sumber hibah manapun.

\section{Konflik Kepentingan}

Seluruh penulis menyatakan tidak terdapat potensi konflik kepentingan dengan penelitian, kepenulisan (authorship), dan atau publikasi artikel ini.

\section{Daftar Pustaka}

1. American Cancer Society. Key statistics for breast cancer in men. Tersedia dari: www.cancer.org.

2. Mistry M, Parkin DM, Ahmad AS, Sasieni P. Cancer incidence in the United Kingdom: Projections to the year 2030. Br J Cancer. 2011;105(11):1795-803. doi: 10.1038/bjc. 2011.430

3. Kementerian Kesehatan Republik Indonesia. Hari kanker sedunia 2019. Jakarta: Kementerian Kesehatan Republik Indonesia; 2019.

4. Kementerian Kesehatan Republik Indonesia. Hasil utama riset kesehatan dasar. Jakarta: Kementerian Kesehatan Republik Indonesia; 2018.

5. Ferlay J, Soerjomataram I, Dikshit R, Eser S, Mathers C, Rebelo M, et al. Cancer incidence and mortality worldwide: Sources, methods and major patterns in GLOBOCAN 2012. Int J Cancer. 2015; 136(5):E359-86. doi: 10.1002/ijc. 29210

6. Pusat Data dan Informasi Kementerian Kesehatan Republik Indonesia. Info DATIN. Jakarta: Kementerian Kesehatan Republik Indonesia; 2015.

7. Heidenreich A, Bellmunt J, Bolla M, Joniau S, Mason M, Matveev V, et al. 
EAU guidelines on prostate cancer. Part 1: Screening, diagnosis, and treatment of clinically localised disease. Eur Urol. 2011;59(1):61-71. doi: 10.1016/j.eururo. 2010.10.03

8. Arunachalam C, Narmadhapriya D. MONASCUS fermented rice and its beneficial aspects: A new review. Asian J Pharm Clin Res. 2011;4(1):29-31.

9. Lee CI, Lee CL, Hwang JF, Lee YH, Wang JJ. Monascus-fermented red mold rice exhibits cytotoxic effect and induces apoptosis on human breast cancer cells. Appl Microbiol Biotechnol. 2013;97(3):1269-78. doi: 10.1007/s0025 3-012-4279-6

10. Cheng CF, Pan TM. Monascus-fermented red mold dioscorea protects mice against alcohol-induced liver injury, whereas its metabolites ankaflavin and monascin regulate ethanol-induced peroxisome proliferator-activated receptor- $\gamma$ and sterol regulatory element-binding transcription factor-1 expression in HepG2 cells. J Sci Food Agric. 2017;98(5):1889-98. doi: $10.1002 /$ jsfa. 8670

11. Shang XY, Li JJ, Liu MT, Li S, Liu Y, Wang YF, et al. Cytotoxic steroids from Monascus purpureus-fermented rice. Steroids. 2011;76(10-11):1185-9. doi: 10. 10 16/j.steroids.2011.05.008

12. Dogra P, Kumar D. Characterization of Monascus purpureus isolated from red yeast rice and its evaluation for the production of cholesterol lowering lovastatin. Biol Forum. 2017;9(1):70-6.

13. Indrawati I, Fakhrudin SD. Isolasi dan identifikasi jamur patogen pada air sumur dan air sungai di Pemukiman Warga Desa Karangwangi, Cianjur, Jawa Barat. J Biodjati. 2016;1(1):27-38. doi: 10.15575/ biodjati.v1i1.1017

14. Cancer Chemoprevention Research Center (CCRC). Prosedur tetap uji sitotoksisitas metode MTT. Yogyakarta: Fakultas Farmasi Universitas Gadjah Mada; 2010.

15. Mostafa ME, Abbady MS. Secondary metabolites and bioactivity of the Monascus pigments. Glob J Biotechnol Biochem. 2014;9(1):1-13.

16. Arbakariya A, Musaalbakri AM, Rosfarizan M. The morphology and structure of red pigment producing fungus: Monascus purpureus. J Microbiol Exp. 2017;5(1):43106.

17. Ismail AI, Hasim, Falah S, Faridah DN. $\alpha$-glucosidase inhibition by red yeast rice extract and fractions as in vitro antidiabetes. Der Pharma Chem. 2016;8 (22):46-9.

18. Cheng MJ, Der MWU, Chen IS, Yang PS, Yuan GF. Secondary metabolites isolated from the fungus Monascus pilosus. Rev Roum Chim. 2010;55(5):335-41. doi: 10. 1002/chin.201051206

19. Subarnas A, Diantini A, Abdulah R, Zuhrotun A, Yamazaki C, Nakazawa M, et al. Antiproliferative activity of primatesconsumed plants against MCF-7 human breast cancer cell lines. E3 J Med Res. 2012;1(4):38-043.

20. Xu B, Wang Q, Sung C. Telomerase inhibitory effects of red pigment rubropunctatin and statin monacolin $\mathrm{L}$ isolated from red yeast rice. Genes (Basel). 2017;8(5):129. doi: 10.3390/genes8050129

21. Batra P, Sharma AK. Anti-cancer potential of flavonoids: Recent trends and future perspectives. 3 Biotech. 2013;3(6):43959. doi: 10.1007/s13205-013-0117-5

(C) 2021 Milanda et al. The full terms of this license incorporate the Creative Common Attribution-Non Commercial License (https://creative commons.org/licenses/by-nc/4.0/). By accessing the work you hereby accept the terms. Non-commercial use of the work are permitted without any further permission, provided the work is properly attributed. 